\section{Death Due to a Combination of Treatment and Disease}

\section{British Medical fournal, 1969, 4, 344}

The use of neostigmine for the treatment of megacolon is well recognized. Complications of this therapy are unusual; we therefore wish to record a fatality from a direct combination of treatment and disease. We can find only one previously recorded case of this nature (Marchand, 1959).

\section{CASE REPORT}

The patient was a 9-year-old girl who had been diagnosed as suffering from megacolon at the age of 6 months. At the age of 3 years neostigmine, 3.75 to $7.5 \mathrm{mg}$. daily, was added to bisacodyl. At the age of 7 years the dose of neostigmine was increased to $15 \mathrm{mg}$. daily. Digital removal of impacted faeces was necessary on several occasions, twice under general anaesthesia. On three occasions after vomiting she had partially or completely collapsed, with muscle twitching. This had prompted an E.E.G., which was normal.

The child presented at 8.30 one evening, apparently with her customary stoppage. She had had sickness and diarrhoea seven and five days before respectively, but had taken six of the normal seven doses of neostigmine and bisacodyl; the last bowel action had been four days previously. A suppository (bisacodyl) at 8.30 p.m. was largely ineffective; two hours later she was sick while straining at stool, and fainted in what was described as "a stiff, cramped way." Later she was noticed to be bubbling saliva and mucus, and at midnight advice was sought. The girl was limp, bubbly, a fair colour; she complained that she could not swallow, but her voice was quite controlled and audible. The.pulse rate was 60 a minute, the heart sounds forceful and regular, and the chest resonant with only a few inspiratory rhonchi. The abdomen was distended with generalized tenderness but there was no guarding or rigidity; bowel sounds were not heard. Examination of the throat showed no abnormality and the tongue was clean. Rectal examination showed a mass of impacted faeces of duck-egg size. Sips of water were taken without difficulty but were regurgitated with mucus and saliva when she lay down. Digital removal of the impaction caused moderate distress. Fibrillation of the leg muscles was noted at this time, but the anal sphincter contracted well and the patient showed some improvement. One hour later her condition deteriorated; she complained of inability to move her legs and of shortness of breath, which was eased by standing and having her hands held out in front of her. Her pupils were contracted. Deterioration continued in the subsequent 15 minutes to total apnoea and death.

At necropsy some cyanosis of the fingers was present, but the main abnormality was within the abdominal cavity, which was very distended owing to the presence of a grossly dilated large intestine filled with more than a litre of very liquid faeces.

The action of neostigmine is through its anticholinesterase activity, and it therefore prolongs or intensifies the action of acetylcholine released from parasympathetic and motor nerve endings. The drug increases sweating, salivary, and gastric secretions, and the motility of the gastrointestinal and urinary tract. It also slows the heart rate (British National Formulary, 1968). The group of drugs to which neostigmine belongs also augment neuromuscular transmission in voluntary muscles, and their direct application causes pupillary contraction. Many of the actions of this drug are illustrated in this case-for example, excess salivation, a large intestine filled with liquid faeces, a slow pulse rate, muscular twitching, and small pupils.

Confirmation of neostigmine overdose was sought and serum cholinesterase on necropsy blood was determined by the method of
Ellman, Courtney, Andres, and Featherstone (1961), using butyrylthiocholine as substrate. Eight replicate estimations gave a mean serum cholinesterase level of $0.16 \mu$ mole substrate hydrolysed/ minute $/ \mathrm{ml}$. serum. Serum proteins were estimated by the method of Lowry, Rosebrough, Farr, and Randall (1951), and the mean value obtained from four estimations was $128 \mathrm{mg} . / \mathrm{ml}$. Thus the serum cholinesterase could be expressed as $0.0013 \mu$ mole substrate hydrolysed/minute/mg. protein. Blood from three healthy persons and three other necropsy cases was also analysed.

\begin{tabular}{|c|c|c|c|}
\hline & $\begin{array}{c}\text { Cholinesterase/ } \\
\text { ml. Serum }\end{array}$ & $\begin{array}{l}\text { Protein } \\
\text { mg./ml. }\end{array}$ & $\begin{array}{c}\text { Cholinesterase/ } \\
\text { mg. Protein }\end{array}$ \\
\hline $\begin{array}{l}\text { Present case } \\
\text { Necropsy samples (mean) } \\
\text { Healthy samples (mean) }\end{array}$ & $\begin{array}{l}0.16 \mu \text { mole } \\
3.50 \mu \text { mole } \\
1.09 \mu \text { mole }\end{array}$ & $\begin{array}{l}128 \\
101 \\
75\end{array}$ & $\begin{array}{l}0.0013 \mu \text { mole } \\
0.0347 \mu \text { mole } \\
0.0145 \mu \text { mole }\end{array}$ \\
\hline
\end{tabular}

Comparison with the healthy controls and with the necropsy samples collected after the same period as the original sample showed that, in terms of serum protein, the serum cholinesterase was considerably lowered, and that haemoconcentration had occurred which gave an artificially high level of serum cholinesterase when activity was expressed as per ml. serum.

\section{COMMENT}

The mechanism of neostigmine overdose appears to be identical with that previously reported. Both cases suffered a period of constipation followed by a return of some gastrointestinal tract motility. Gilman and Goodman (1965) indicate that only a small proportion of administered neostigmine bromide is absorbed from the gastrointestinal tract and that the remainder is largely inactivated or destroyed during passage through the tract. It is postulated that the period of constipation before the development of the signs of overdose allowed the normal daily doses to remain unaltered in the gastrointestinal tract. After the return of gastrointestinal tract motility, due either to a spontaneous mechanism or to artificial aids (a suppository and manual removal in this case), absorption and detoxication of the drug recommenced, but from a reservoir which allowed lethal levels to be attained.

The fatal outcome could possibly have been prevented had the underlying mechanism been considered early in the course of the disease. We suggest that patients on neostigmine for megacolon should cease to take the drug if they have a period of constipation longer than two to three days.

JAMES C. BRIGGS, M.B., M.C.PATH. W. E. Dobson-SMYTH, M.B.

A. Livingston, PH.D.

Frenchay Hospital, Bristol BS16 1LE, and Department of Pharmacology, University of Bristol BS8 ITD.

\section{REFERENCES}

British National Formulary, 1968, p. 82. London, British Medical Association and the Pharmaceutical Society of Great Britain. Ellman, G. L., Courtney, K. D., Andres, V., jun., and Featherstone,
R. M. (1961). Biochemical Pharmacology, 7, 88.

Koelle, G. B. (1965). In The Pharmacological Basis of Theropeutics, 3rd ed., edited by L. Goodman and A. Gilman, p. 451. New York, Macmillan.

Lowry, O. H., Rosebrough, N. J., Farr, A. L., and Randall, R. J. (1951). foumal of Biological Chemistry, 193, 265.

Marchand, W. (1959). Gastroenterology, 36, 877. 